\title{
English: The Extent of Viking Impact Remains Open
}

\author{
Ans van Kemenade \\ Radboud University Nijmegen \\ A.v.Kemenade@let.ru.nl
}

\begin{abstract}
Emonds \& Faarlund's assessment of the language contact situation between AngloSaxons and Vikings is ill-informed historically. I furthermore discuss a number of instances where their analysis of Scandinavian linguistic impact on English is based on overly hasty interpretations of the literature.
\end{abstract}

\section{Keywords}

historical syntax - language contact - history of English - Germanic

The most articulate and far-reaching version of Scandinavian influence on English so far was Townend (2002), who pushes a carefully documented argument to the conclusion that Old Norse and Old English (OE) were mutually intelligible, that there was societal though not individual bilingualism in Anglo-Saxon times in the Danelaw area, and that Old Norse died out at some point. There is room for disagreement with Townend's conclusions, but in fact any reference to Townend is missing in Emonds and Faarlund's (E\&F) bibliography, along with the rest of the specialized literature (e.g., Brink and Price, 2008). New and challenging hypotheses are always welcome, to inform hypotheses where contemporary direct evidence is scant, but they require a historical and a linguistic foundation that will stand up to scrutiny. Neither of them does: E\&F's historical scenario of the death of oE at the hands of Anglicized Norse is as radical as it is implausible, and their linguistic arguments are sketchy and often ill-founded. In fact, they have not done their homework. 
E\&F's primary aim is to show that the grammatical skeleton of Middle English (ME) is that of what they call Anglicized Norse. They seem to assume very clear-cut distinctions between the early North and West Germanic languages, attributing any differences between $\mathrm{OE}$ and $\mathrm{ME}$, and any similarities between ME and Old Norse, to Anglicized Norse as a source, ignoring much of the literature on $\mathrm{OE}$, ignoring what was going on in the other West Germanic languages, and never considering a case for microvariation and/or convergent evolution. Space only permits brief critical discussion of some examples.

E\&F list vo syntax among the Norse properties of ME lacking in OE. It is certainly plausible that the loss of ov word orders was accelerated by contact with Scandinavian, but this provides no argument for E\&F's case, which is that English has become Norse when there is substantial loss of ov by ME. They ignore a core fact from Pintzuk's (2002) work (cited in their bibliography): OE had substantial vo word order beside various types of ov. E\&F then go on to identify as Norse the 15th-century word order pattern with preverbal negated objects with a similar pattern in present-day Icelandic, further ignoring the firmly established continuity between $\mathrm{OE}$ and late $\mathrm{ME}$ OV orders with negated objects (Pintzuk and Taylor, 2006, cited in their bibliography).

Another property listed as Old Norse and lacking in OE is the use of shall and will as auxiliaries marking future meaning ( $78 \mathrm{ff}$.). Ignoring the oE facts (Denison, 1993: 304 and Warner, 1993: 168ff. record future uses of modals in $\mathrm{OE})$, it seems we are now to accept stages of grammaticalization processes as borrowing sources. In the same vein, ME shows occasional examples combining two modals, which E\&F attribute on p. 81 to Norse as a source. Coupé and van Kemenade (2009) and Coupé (2015) show, on the other hand, that cooccurrence of modals is sporadically attested in the 13th century across the West Germanic languages, starting with the most grammaticalized modal shall. Such sequences of modals made a hesitant start in ME but failed to catch on in the way E\&F would have to expect.

Verb Second (V2) is a Norse-influenced ME innovation lacking in Old English, according to E\&F (pp. $108 \mathrm{ff}$.). Old as well as Middle English have a complex variant of V2 (e.g., van Kemenade, 2012), but one heavily Norse-influenced 15thcentury text shows the standard Germanic categorical v2 pattern (Kroch and Taylor, 1997). However much we try to make of this, E\&F would predict that English, if descending from Anglicized Norse, has categorical v2, but the fact is that it has relic V2 in a restricted set of constructions such as questions, where it has had it since the earliest times.

A putative victim of Norse influence (pp. 114-115) are inherent reflexives marked by an object personal pronoun, Norse having drastically reduced its designated reflexive marker sik. Other West Germanic languages, like Dutch- 
and as far as we can tell not due to contact with Norse-also lost reflexive marking by object personal pronouns, which in Dutch gave rise to reflexive marking by a designated reflexive pronoun zich, the cognate of Old Norse sik (Postma, 2012).

These few examples are representative of the general repertoire of arguments; notwithstanding the well-known and profound effect of contact with Norse on the historical development of English, which could do with a good deal more informed study, Anglicized Norse makes an unlikely ancestor of Modern English.

\section{References}

Brink, Stefan and Neil Price (eds.). 2008. The Viking World. London/New York: Routledge.

Coupé, Griet. 2015. Syntactic Extension-The Historical Development of Dutch Verb Clusters. PhD dissertation, Radboud University Nijmegen.

Coupé, Griet and Ans van Kemenade. 20og. Grammaticalization of modals in English and Dutch: Uncontingent change. In Paola Crisma and Giuseppe Longobardi (eds.), Historical Syntax and Linguistic Theory, 250-270. Oxford: Oxford University Press.

Denison, David. 1993. English Historical Syntax: Verbal Constructions. London/New York: Longman.

Kroch, Anthony and Ann Taylor. 1997. Verb movement in Old and Middle English: Dialect variation and language contact. In Ans van Kemenade and Nigel Vincent (eds.), Parameters of Morphosyntactic Change, 297-325. Cambridge: Cambridge University Press.

Pintzuk, Susan. 2002. Verb-object order in Old English: Variation as grammatical competition. In David Lightfoot (ed.), Syntactic Effects of Morphological Change, 276299. Oxford: Oxford University Press.

Pintzuk, Susan and Ann Taylor. 2006. The loss of ov order in the history of English. In Ans van Kemenade and Bettelou Los (eds.), The Handbook of the History of English, 249-278. Oxford: Blackwell Publishing.

Postma, Gertjan. 2012. Language contact and linguistic complexity-the rise of the reflexive pronoun zich in a fifteenth-century Netherlands border dialect. In Dianne Jonas, John Whitman, and Andrew Garret (eds.), Grammatical Change: Origins, Nature, Outcomes, 139-159. Oxford: Oxford University Press.

Townend, Matthew. 2002. Language and History in Viking Age England: Linguistic Relations between Speakers of Old Norse and Old English. Turnhout: Brepols Publishers.

Warner, Anthony. 1993. English Auxiliaries: Structure and History. Cambridge: Cambridge University Press. 